\title{
Inheritance of resistance to downy mildew (Pseudoperonospora cubensis) in muskmelon (Cucumis melo). I. Analysis of a $8 \times 8$ diallel table
}

\author{
C Épinat ${ }^{1 *}, \mathrm{M} \mathrm{Pitrat}^{2}$ \\ 1 INRA, Station de Génétique Végétale, Ferme du Moulon, F91190 Gif-sur-Yvette; \\ 2 INRA, Station d'Amélioration des Plantes Maraîchères, BP 94, F84143 Montfavet Cedex, France
}

(Received 27 August 1993 ; accepted 12 April 1994)

\begin{abstract}
Summary - The genetics of resistance to downy mildew (Pseudoperonospora cubensis) in the muskmelon (Cucumis melo) was studied by means of a half diallel table between 8 inbred lines. The sample chosen exhibited a continuous variation for the resistance character ranking from a high level of resistance to high susceptibility. Analysis of variance detected highly significant general combining ability effects. Although significant, the specific combining ability effects had a low impact on total variation and therefore the presence of heterosis for resistance was not revealed. Decomposition of dominance variation indicated that the dominance effect was not unidirectional and that dominant genes were not uniformly distributed among the parents. These facts were confirmed and further detailed using Hayman's graphical analysis. Narrow-sense heritability estimates were high $(0.82-0.88)$. Tests of the hypotheses underlying Hayman's diallel analysis were performed and discussed.
\end{abstract}

\section{Cucumis melo / diallel / inheritance / Pseudoperonospora cubensis / partial resistance}

Résumé - Hérédité de la résistance au mildiou (Pseudoperonospora cubensis) chez le melon (Cucumis melo). I. Analyse d'un plan diallèle $\mathbf{8 \times 8}$. L'hérédité de la résistance du melon (Cucumis melo) au mildiou (Pseudoperonospora cubensis) a été étudiée à l'aide d'un demi-plan de croisement diallèle à 8 parents. L'échantillon choisi montre une variation continue pour le caractère de résistance, depuis l'extrême sensibilité jusqu'à la résistance de très haut niveau. L'analyse de variance a mis en évidence l'importance des effets d'aptitude générale à la combinaison. Les effets d'aptitude spécifiques à la combinaison, bien que significatifs, ont un faible impact sur la variation totale et ne permettent pas de conclure à la présence d'hétérosis pour la résistance. La décomposition de la variation de dominance indique que les effets de dominance ne sont pas unidirectionnels ni distribués de façon indépendante entre les parents. Ces résultats ont été confirmés par l'analyse graphique de Hayman (1954). Les estimations des héritabilités au sens strict sont élevées $(0,82-0,88)$. Des tests des différentes hypothèses sous-jacentes à l'analyse diallèle selon Hayman ont été réalisés et discutés.

Cucumis melo / diallèle / hérédité /Pseudoperonospora cubensis / résistance partielle

* Correspondence and reprints. 


\section{INTRODUCTION}

Downy mildew caused by Pseudoperonospora cubensis (Berk and Curt) Rost inflicts severe damage on cucurbits in humid areas of production throughout the world. The disease has only recently appeared in France on melon cultures. The first damaging infestation can be dated from 1984. Since that time, the disease has been commonly found in the main French production areas (south-east, south-west and central-west). Currently, the principal method of controlling this disease is the use of protective fungicides. Systemic fungicides such as Metalaxyl were highly effective against peronosporaceous fungus but this product has lost its efficacy because of the occurrence of resistant races of the fungus (Reuveni et al, 1980). Moreover, environmental and economic considerations have strengthened emphasis on the development of commercially acceptable resistant cultivars.

The basic sources of resistance in muskmelons were found to be from Indian plant introductions (Thomas, 1982). According to a recent survey on a collection of 400 lines, resistance to downy mildew shows a continuous variation (Pitrat et al, 1989). As opposed to qualitative resistance, quantitative or partial resistance may reduce the selection pressure for virulence in the pathogen population and could thus stabilize the host-pathogen system (Crill, 1977). The genetics of these forms of resistance have not been extensively studied. Some authors evaluated resistance on a discontinuous scale (reaction types on a 1-4 scale in Thomas et al, 1988; Kenigsbuch and Cohen, 1992), others measured the number of sporangia (Cohen et al, 1985), but all finally place the individuals in 3 classes: resistant; intermediate; and susceptible. They all reported monogenic or digenic control with a rough indication of the level of dominance (characterized as 'intermediate' or 'partial'). Moreover, these authors generally considered a single 'resistant $x$ susceptible' cross in their studies and no comparisons between cultivars were possible.

In this paper, we investigate the genetics of quantitative resistance to downy mildew in a $8 x$ 8 diallel cross on the $F_{1}$ generation. The reaction types of the parents formed a continuous series from a high level of resistance to a high level of susceptibility.

\section{MATERIAL AND METHODS}

\section{Genetic material}

A sample of 8 melon lines were chosen as representative of the reaction types toward $P$ cubensis observed in a collection of 400 lines. Four cultivars were from India: 'MR-1' (higher level of resistance: infected leaves showed no sporulation but pin-prick brown lesions); 'PI 124112' (small brown lesions and traces of sporulation on infected leaves); 'PI 164323' (small necrotic lesions with light sporulation); and 'PI 414723' (medium-sized brown lesions with light sporulation). 'Edisto 47' is an American variety derived from ' $\mathrm{PI}$ 124112 ' (medium-sized brown lesions with moderate sporulation); 'Védrantais' and 'Charentais T' are 2 susceptible lines in the Charentais type commonly cultivated in France (with 'Védrantais' slightly more susceptible than 'Charentais T'); and 'Ouzbèque' is a highly susceptible line from Uzbekistan.

The 8 melon lines were crossed in all possible combinations including reciprocals to produce $F_{1}$ seeds. Fourteen replications of the half diallel including the parents (36 genotypes and 10 plants per genotype) were evaluated for resistance to $P$ cubensis. Three replications of the full diallel have previously indicated of the absence of reciprocal or maternal effects (Épinat, 1992).

\section{Isolates and conservation techniques}

Among the 16 isolates maintained at the 'Station de Pathologie Végétale' of Montfavet in 1989, no physiological specialization was observed towards our host sample (Épinat, 1989). We chose to maintain the most agressive of the 16 strains instead of a mixture of races, because of the possible occurrence of interactions between races that do not possess the same avirulence genes (in particular, the phenomenon of induced resistance). According to the classification of Thomas et al (1987), our strain is pathotype 3 (Épinat, 1992).

The technique of pathogen conservation was described in 1989 by Blancard et al. Young cotyledons were cut off and placed upper-face-upwards on a filter paper moistened with distilled water in a closed plastic box (100\% RH). A $50 \mathrm{ml}$ drop (5000 sporangia per $\mathrm{ml}$ ) was deposited on the cotyledon. After 6-9 d spent in a growth chamber $\left(12 \mathrm{~h}\right.$ per d, $25^{\circ} \mathrm{C}, 5000$ lux; $12 \mathrm{~h}$ night, $18^{\circ} \mathrm{C}$ ), there was abundant sporulation on the susceptible cultivar. These cotyledons may be stored for $4-5$ months if frozen at $-17^{\circ} \mathrm{C}$. This method was used to produce great quantities of inoculum.

\section{Plant culture and inoculation procedure}

All plants were grown in $8.5 \mathrm{~cm}$ pots in the greenhouse. At the 2-3 leaf stage, disks $(20 \mathrm{~mm}$ diameter 
and 4 disks per plant) were cut from the last 2 expanded leaves and placed lower-face-upwards on moistened filter paper in clear polystyrene boxes. The process of inoculation was the same as before: a drop $(50 \mathrm{ml})$ of a suspension of sporangia (5000 sporangia per $\mathrm{ml}$ ) was deposited on each leaf disk. Closed boxes were incubated for $8 \mathrm{~d}$ in growth chambers at $24^{\circ} \mathrm{C}$ for $12 \mathrm{~h}$ light and at $18^{\circ} \mathrm{C}$ for $12 \mathrm{~h}$ of dark.

\section{Disease rating}

Eight days after inoculation, sporulation was recorded on a scale of 0 (no sporulation) to 9 (disk completely covered with heavy sporulation). The score was the visual evaluation of the percentage of disk surface covered with sporulation (notation was made under the binoculars). The final score of a plant was the mean of the 4 leaf disks scores.

\section{Data analysis}

Analyses of variance (GLM program, SAS Institute, 1988) were performed on mean scores per plant. The 14 replications of the half diallel were in fact different sowing dates through 1991 and variation among the replications was considered as an environmental random effect. The general combining ability (GCA) and the specific combining ability (SCA) effects for the parents and crosses, respectively, were estimated following Griffing's (1956) model 2 (parents and one set of $F_{1}$ crosses). We chose a fixed model for genotypic effects because our 8 parents could not be considered as a random sample:

$$
\begin{aligned}
y_{i j k l} & =\mu+g_{j}+g_{j}+s_{i j}+e_{k}+e_{k} \times g_{i} \\
& +e_{k} \times g_{j}+e_{k} \times s_{i j}+\varepsilon_{i j k l}
\end{aligned}
$$

where $g_{i}\left(g_{j}\right)$ is general combining ability effect, $s_{i j}$ is specific combining ability effect, $e_{k}$ is the environmental effect, and $e_{k} \times g_{i}, e_{k} \times g_{j}$ and $e_{k} \times s_{i j}$ are genotypic environmental interactions.

The data were then analysed as described by Hayman (1954). The diallel cross was assumed to meet the general assumptions of this analysis. We consider here a traditional fixed model with a descendence population reference, ie all inferences are to be made to the population that would be developed from the diallel parents by several generations of random mating (Wright, 1985). Hayman's (1954) analysis of variance was performed according to the model:

$$
\begin{aligned}
y_{i j k l} & =\mu+a_{i}+a_{j}+b_{i j}+e_{k}+e_{k} \times a_{i} \\
& +e_{k} \times a_{j}+e_{k} \times b_{i j}+\varepsilon_{i j k l}
\end{aligned}
$$

where $a_{i}$ is the mean deviation due to the ith parent, $b_{i j}$ is the remaining discrepancy attributable to dominance effect, $e_{k}$ is the environmental effect, and $a_{i} \mathrm{x}$ $e_{k}$ and $b_{i j} \times e_{k}$ are genotypic environmental interactions.
Hayman's analysis of variance provided a further decomposition of dominance effect (b) in $b_{1}, b_{2}$, and $b_{3}$ effects: $b_{i j}=b_{1}+b_{2 i}+b_{3 i j}$, where $b_{1}$ is the overall mean dominance deviation, $b_{2 i}$ indicated the dominance deviation due to the th parent, and the definition of the $b_{3 i j}$ component is equivalent to the SCA effect of Griffing; $b_{3 i j}$ represents the dominance deviation that is unique to each $\mathrm{F}_{1}$ cross (ij).

The method of Hayman includes the construction of a $V, W_{r}$ graph, where $V_{r}$ is the variance of each array (all the progeny of a given parent) and $W_{r}$ is the covariance between progenies involving the recurrent parent and the non-recurrent parent. The position of the parents in this plot shows the percentage of dominant and recessive alleles controlling the character. To check the validity of the assumptions we tested the adequation of the regression line $\left(V_{r}, W_{r}\right)$ to a line of unit slope. The absence of epistasis was roughly tested on parental and $F_{1}$ generations as suggested by Allard (1957). Epistasis comparable to the complementary types of gene interactions was present if $W_{r} / V_{r}<1$ and $2 W_{r p} W_{r}>1$, where $W_{r p}$ is the covariance between crosses involving the recurrent parent and the mean of the crosses involving the non-recurrent parent. Finally, the estimation of components of genetic variation $(D$. additive variation, $H 1$ : non-additive variation, $H 2$ : nonadditive variation weighted by gene distribution among parents, and $F$ : covariation between additive and nonadditive effects) was made following Hayman's method.

\section{RESULTS}

\section{Analysis of variance}

\section{Griffing's model}

Analysis of variance following Griffing's decomposition proved significance of GCA and SCA effects, as well as their interactions with environment (table I). Values for GCA with their corresponding variances are summarized in table II. The highly negative GCA values obtained for the first 3 parents indicate a high degree of resistance (varieties 'MR-1', 'PI 124112' and 'PI 164323'). More generally, GCA effects were highly correlated to parental performances: GCA was non-significant for 'Edisto 47' and positive for all susceptible genotypes. Parents showing a substantial variation in GCA value, 'MR-1' and 'Ouzbèque' were the most resistant parent and the most susceptible parent, respectively.

\section{Hayman's model}

Results of Hayman's analysis of variance (table III) were in agreement with the results of 
Table I. Analysis of variance of the half diallel following Griffing's method 2 with a mixed model (fixed genotypic effects and random environmental effects). The experiment included 14 environments and 36 genotypes (8 parents).

\begin{tabular}{lccc} 
Effect & Degrees of freedom & Mean squares & Fisher test \\
\hline Environment & 13 & 196.31 & $26.24^{*}$ \\
& & & \\
Crosses & 35 & 645.99 & $86.36^{*}$ \\
$\quad$ GCA & 7 & 3126.17 & $417.94^{*}$ \\
SCA & 28 & 26.00 & $3.47^{*}$ \\
Environment x crosses & 455 & 7.48 & $7.79^{*}$ \\
Environment x GCA & 91 & 12.59 & $13.11^{*}$ \\
Environment x SCA & 364 & 6.20 & $6.46^{*}$ \\
Error & & 0.96 & \\
\end{tabular}

*, significant at $P=0.01$.

Table II. Individual effects $g_{i}(\mathrm{GCA})$ according to Griffing's model with their standard deviation estimators.

\begin{tabular}{llll}
\hline Parent & Mean score & $G C A_{\mathrm{i}}$ & $\sigma$ \\
\hline MR-1 & 0.07 & $-1.82^{*}$ & 0.64 \\
$\mathrm{PI} \mathrm{124112}$ & 0.19 & $-1.32^{*}$ & 0.47 \\
$\mathrm{PI} 164323$ & 0.51 & $-1.06^{*}$ & 0.37 \\
$\mathrm{PI} 414723$ & 1.05 & $-0.63^{*}$ & 0.22 \\
Edisto 47 & 2.95 & $-0.02^{\mathrm{n}}$ & 0.01 \\
Charentais T & 5.23 & $0.98^{*}$ & 0.35 \\
Védrantais & 6.31 & $1.40^{*}$ & 0.50 \\
Ouzbèque & 7.75 & $2.47^{*}$ & 0.87 \\
\hline
\end{tabular}

* Mean significant at $P=0.05 ; \mathrm{ns}=$ mean non-significant.

Griffing's analysis. Mean squares for environment, additivity, dominance and all interactions with environment were also significant. The overall mean dominance deviation $b_{1}$ was non-significant, and so the dominance effect was not unidirectional. The $b_{2}$ component was highly significant and indicated that dominant genes were not uniformly distributed among parents (some parents had more dominant alleles than others). The significance of the $b_{3}$ component confirmed the presence of specific dominance or combining ability in some crosses.

\section{Genotype x environment effects}

Considering the 14 environments, all genotype $x$ environment interactions had highly significant effects $(P<0.01$ in tables I and III). The genotypic effect explained $68.6 \%$ of the total variance whereas $7.8 \%$ of the variance was attributable to environmental effects. The genotype $x$ environment interaction explained $10.4 \%$ of the variance and could not be neglected. However, we observed (data not shown) that this interaction did not result in many ranking crossovers, so further analysis was performed on genotypic values.

\section{Hayman's graphical analysis of the diallel}

If all the assumptions underlying the analysis were met, $W_{r}-V_{r}$ would be a constant (Hayman, 1954). Analysis of variance of $\left(W_{r}-V_{r}\right)$ (table IV) for the 14 environments, attested the constancy of the quantity among the parents (the parental 
Table III. Analysis of variance of the half diallel according to Hayman's model. The experiment included 36 genotypes, 14 environments and 10 repetitions per genotype and per environment.

Effect Degrees of freedom Mean squares Fisher test

\begin{tabular}{|c|c|c|c|}
\hline Environment & 13 & 196.31 & 26.24 * \\
\hline Additivity & 7 & 3126.17 & 248.30 * \\
\hline Dominance & 28 & 25.95 & $4.18^{*}$ \\
\hline$b_{1}$ & 1 & 23.17 & $1.43^{\mathrm{ns}}$ \\
\hline$b_{2}$ & 7 & 51.75 & $8.05^{*}$ \\
\hline$b_{3}$ & 20 & 17.06 & 3.03 \\
\hline Crosses & 35 & 645.99 & 86.36 * \\
\hline Additivity $\mathrm{x}$ environment & 91 & 12.59 & 13.11 * \\
\hline Dominance $\mathrm{x}$ environment & 364 & 6.20 & $6.46^{*}$ \\
\hline$b_{1} \times$ environment & 13 & 13.23 & $16.91^{*}$ \\
\hline$b_{2} \times$ environment & 91 & 6.43 & $6.70^{*}$ \\
\hline$b_{3} \times$ environment & 260 & 5.62 & $5.85^{*}$ \\
\hline Crosses $\mathrm{x}$ environment & 455 & 7.48 & \\
\hline Error & 4243 & 0.96 & \\
\hline
\end{tabular}

* Significant at $P=0.01 ; \mathrm{ns}$, non-significant.

Table IV. Analysis of variance of $W_{r}-V_{r}$ quantities (Hayman 1954). Absence of parental effect indicates absence of epistasis.

$\begin{array}{lrrr}\text { Total } & 111 & & \\ \text { Parental effect } & 7 & 0.19 & 1.09 \mathrm{~ns} \\ \text { Environment } & 13 & 1.56 & 8.79^{*} \\ \text { Error } & 91 & 0.18 & \end{array}$

\footnotetext{
* Significant at $P=0.01 ;$ ns: non-significant.
}

effect was non-significant). The mean regression slope of $W_{r}$ on $V_{r}$ was significantly different from unity $(0.90 \pm 0.06$ at $95 \%$ confidence). The failure of one or some hypotheses was probable. However, the deviation of the regression slope from unity appeared small enough to allow further analysis of the data. Indeed, the removal of any one of the 8 parents from the analysis did not significantly improve or alter the previous results (data not shown).

A test for epistasis (Allard, 1957) on the $F_{1}$ generation indicated the probable absence of epistasis of the complementary type in the diallel table (table $\mathrm{V}$ ).

Hayman's graph $\left(W_{r}, V_{r}\right)$ for resistance to downy mildew is presented in figure 1 . No relationship between resistant/dominant types and susceptible/recessive types was apparent. 'MR-1' and 'PI 124112' (located in the lower part of the graph) were the most dominant parents whereas 'PI 414723' (intermediate type) was the most recessive parent. The highly susceptible parent ('Ouzbèque') had approximately the same position as 'PI 164323' (resistant type) and 'Edisto 
Table $V$ : Analysis of epistasis on parental and $F_{1}$ generations. Epistasis of the complementary type is probable when $W_{v} N_{r}<1$ and $2 W_{r p} W_{r}>1$

\begin{tabular}{|c|c|c|c|}
\hline \multirow{2}{*}{ Parent } & $W_{r}$ & $2 W_{r p}$ & \multirow{2}{*}{ Epistasis presence } \\
\hline & $V_{r}$ & $W_{r}$ & \\
\hline MR-1 & 2.12 & 1.04 & none \\
\hline PI 124112 & 1.70 & 1.03 & none \\
\hline PI 164323 & 1.59 & 1.03 & none \\
\hline PI 414723 & 1.40 & 0.97 & none \\
\hline Edisto 47 & 1.60 & 1.03 & none \\
\hline Charentais $T$ & 1.48 & 1.05 & none \\
\hline Védrantais & 1.48 & 1.03 & none \\
\hline Ouzbèque & 1.46 & 1.07 & none \\
\hline
\end{tabular}

47' (intermediate type). Dominance was obviously non-unidirectional. The conversion of these positions into percentages of dominant alleles is presented in table VI. 'MR1', the most dominant parent, possessed $86 \%$ of dominant alleles whereas the most recessive parent, ' $\mathrm{Pl}$ 414723' still possessed $46 \%$ of dominant alleles.

The relative positions of the regression line and of the tangent to the parabola were representative of a low dominance ratio (whose approximate estimation was given by $\sqrt{A B / O B}=0.51)$.

The estimation of genetic parameters for the half diallel table is presented in table VII. All these parameters were highly significant. $D$ and $H 1$ were the estimates of additive and dominance effects variation so that $\sqrt{H 1 / D=0.56}$ estimated the mean degree of dominance. The agreement with the graphical estimation was good. $H 2$ was the estimation of dominance variation weighted by gene distribution among parents. $H 1$ was significantly different from $H 2$, indicating that gene distribution among parents was not symmetrical. The positive sign for $F$ confirmed that dominant alleles were more frequent than recessive ones, irrespective of whether dominant or non-dominant alleles had increasing or decreasing effects. Narrow sense heritability estimates according to Hayman (1954) and Mather and Jinks (1971) were both very high and are, respectively,

\section{$1 / 4 \quad D$}

$\frac{1 / 4(D-H 1-F)+E}{1 / 2(D+H 1-H 2-F)}=0.82 \quad$ and
$\frac{1 / 2(D+H 1-F)-1 / 4 H 2+E}{1 / 4}=0.88$

\section{DISCUSSION}

The diallel study provided evidence of the existence of significant additive variation through large values of $D$ and $G C A$. As suggested by Baker (1978), the relative importance of GCA and SCA in determining progeny performance should be assessed by estimating the ratio of the mean squares:

$$
\frac{2 \sigma_{g}^{* 2}}{2 \sigma_{g}^{* 2}+\sigma_{s}^{* 2}}
$$

where $\sigma_{\mathrm{g}}{ }^{2}$ and $\sigma_{\mathrm{s}}^{* 2}$ are analogous to GCA and SCA variations, ie sum of squares parameters weighted by the inverse of their degrees of freedom. This ratio equals 0.86 in our case and confirms the high predictability of progeny performance based on GCA alone.

The predominance of additivity has been recently shown in many non-specific host $x$ parasite interactions through diallel analysis, eg, partial resistance to Erysiphe graminis of barley $(6 \mathrm{x}$ 6 diallel in Balkema-Boomstra and Mastebroek, 1993), partial resistance to Phyllachora maydis of maize ( $8 \times 8$ diallel in Ceballos and Deutsch, $1992)$, or partial resistance to Septoria tritici of winter and spring wheat $(6 \times 6$ diallel in Danon and Eyal, 1990).

The presence of dominance effects was indicated in significant $b$ values (dominance component mean squares) in the Hayman analysis of variance. The analysis of $W_{n} V_{r}$ and graphical statistics computed from $F_{1}$ generation provided detailed information on the interrelations between the parents. The positive $W_{r}$ intercept in the graphic analysis suggested partial dominance. The percentages of dominant alleles in resistant 


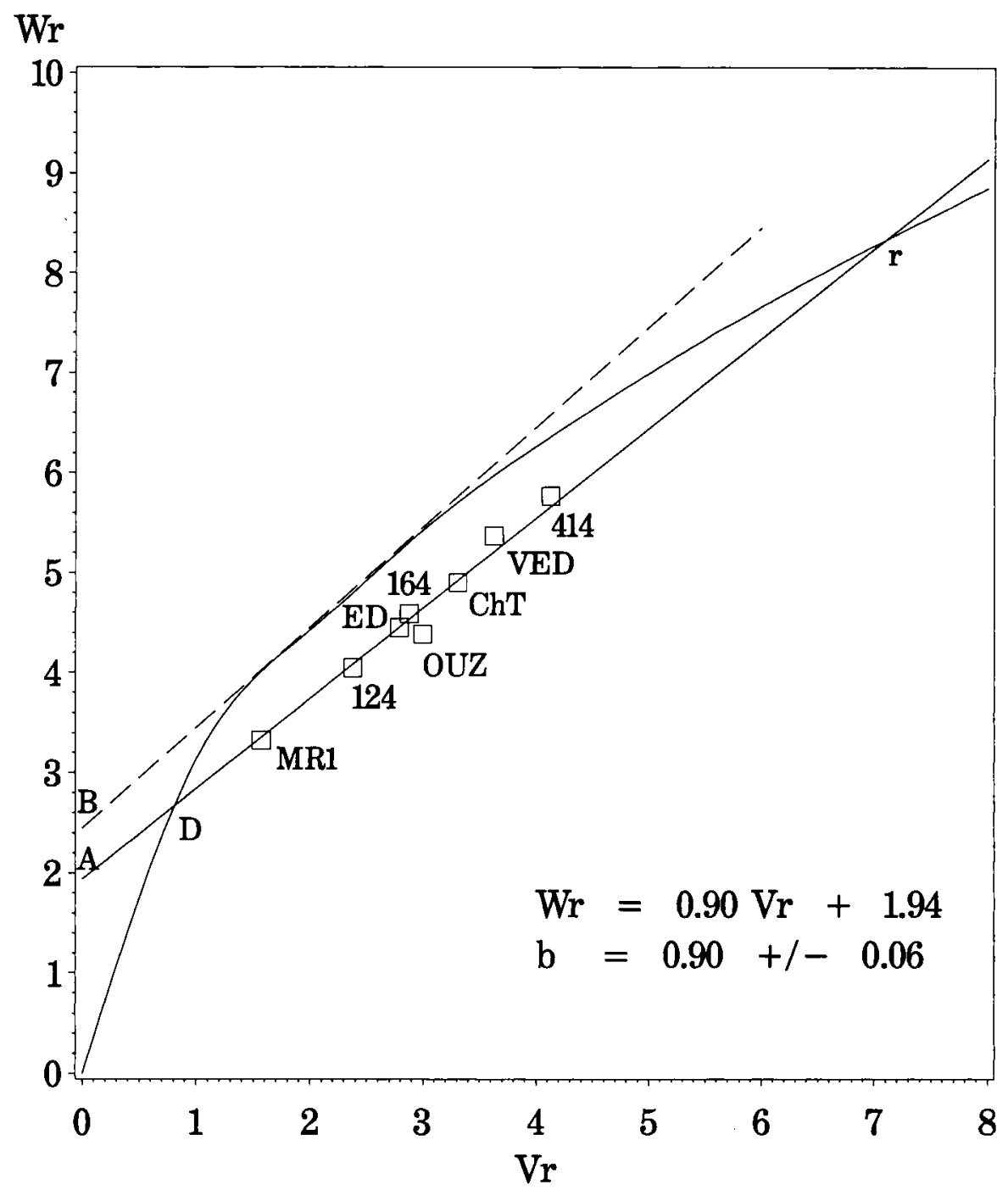

Fig 1. Hayman's graph representing the linear relationship between parents in an $F_{1}$ population of a $8 \times 8$ diallel infected with $P$ cubensis. $V_{r}$ is the variance of all the offspring of each parent in each array, $W_{r}$ is the covariance between these offspring and their non-recurrent parents. Equation of regression line and standard error of the slope $(b)$ are given. The limiting parabola $\left(W_{r}=V_{p} \times V_{r}\right)$ and the tangent to the parabola with slope one are drawn. The position of $\left(V_{r}, W_{r}\right)$ on the line reveals the relative proportions of dominant and recessive genes in the parent $r$. D is the point corresponding to $100 \%$ dominant alleles, $r$ to $100 \%$ recessive alleles.

parents confirmed that dominance effects were not unidirectional and that the sample presented an excess of dominant alleles. Comparison of 2 dominance variation estimations ( $H 1$ and $H 2)$ showed that the gene distribution among parents was not symmetrical. Finally, the apparent differences in dominance effects and degree of resistance between our resistant parents indicated that either these are different sources of resistance located at different loci or that significant effects of their genetic backgrounds affect the final expression of a resistance controlled by a major gene.

The slight deviation from unity of the $\left(W_{r}, V_{r}\right)$ regression line slope obviously indicated an apparent failure of one or more of the hypotheses. The subject had been extensively argued by many authors. Four hypotheses will be discussed here.

\section{Non-independent distribution of genes among parents}

Comparison of both $H 1$ and $H 2$ attested of the failure of this hypothesis in our sample. Kempthorne (1956) and Feyt (1976) considered this assumption impossible to meet, especially with a small number of parents (lower than 10). Hill (1964) concluded that associated distributions among the parents produced an upward curvature in the $W_{r} N_{r}$ graph. He found that gene dispersion did not give any distinctive curvature, but may result in a non-significant $W_{r} N_{r}$ regression. In our study, no significant curvature of the graph was observed and so dispersion is more probable than association. 
Table VI. Presentation of mean values of resistance ratings, $V_{r}$ and $W_{r}$ corrected for environmental effect. The percentage of dominant alleles present in each parent is given.

\begin{tabular}{lllc}
\hline Parent & $\mathrm{V}_{\mathrm{r}}$ & $\mathrm{W}_{\mathrm{r}}$ & $\begin{array}{c}\text { \% of dominant } \\
\text { alleles }\end{array}$ \\
\hline & & & $86 \%$ \\
$\mathrm{MR}-1$ & 1.57 & 3.33 & $73 \%$ \\
$\mathrm{PI} 124112$ & 2.38 & 4.05 & $66 \%$ \\
$\mathrm{PI} 164323$ & 2.88 & 4.59 & $46 \%$ \\
$\mathrm{PI} 414723$ & 4.13 & 5.76 & $67 \%$ \\
Edisto 47 & 2.79 & 4.45 & $59 \%$ \\
Charentais T & 3.31 & 4.90 & $54 \%$ \\
Védrantais & 3.63 & 5.36 & $64 \%$ \\
Ouzbèque & 3.00 & 4.38 &
\end{tabular}

Table VII. Estimation of genetic components of variation for resistance to Pseudoperonospora cubensis for an 8 parent diallel set according to the method of Hayman (1954). The standard deviation of each estimator is given.

\begin{tabular}{llll}
\hline Variance & Estimate & Value & $\sigma$ \\
\hline & & & 0.02 \\
Environmental & $E$ & $0.05^{\star}$ & 0.05 \\
Additive & $D$ & $9.79^{\star}$ & 0.10 \\
Non-additive & $H 1$ & $3.26^{\star}$ & 0.09 \\
Weighted non-additive variation & $H 2$ & $1.40^{\star}$ & 0.10 \\
Covariance additive x non-additive effects & $F$ & & $1.20^{\star}$ \\
\hline
\end{tabular}

\footnotetext{
* Significant at $P=0.01$.
}

\section{Multiple allelism}

There had been little discussion about a failure of this assumption. Incidence of multiple allelism could be confounded with linkage or epistasis in $F_{1}$ generation (Hayman 1954). However, because of the different origins of the 8 parents, multiple allelism must be suspected. Moreover, numerous examples of host $x$ parasite interactions tend to indicate that genes for resistance are likely to be multiallelic (a series of 3 alleles was found on the same cultivars for resistance to powdery mildews by Epinat et al, 1993).

\section{Heterozygous parents}

About 5 generations of inbreeding have been carried out on each of the 8 parents. Some of them might be still partially heterozygous for the loci concerned. Hayman (1954) pointed out that if the parents were heterozygous, there would be some scatter about the regression of $W_{r}$ on $V_{r}$.
Dickinson and Jinks (1956) proposed an analysis for heterozygous parents. They found, by means of simulation, that the regression slope deviated significantly from unity in absence of epistasis. This situation seemed to be well adapted to our data and so the probable failure of this hypothesis cannot be neglected.

\section{Epistasis}

Gilbert (1958) and Baker (1978) found that no epistasis is an unrealistic and non-biological assumption. Powerful tests for epistasis were described by Hayman (1958) using $F_{2}$ generations of a diallel. Considering the $\mathrm{F}_{1}$ generation, the regression of $W_{r}$ on $V_{r}$ should have a regression value of unity. Jinks (1956) reported that this regression test was not sensitive to duplicate gene interaction. Moreover, our test based on the $\left(V_{r}, W_{r}\right)$ and $\left(W_{r p}, W_{r}\right)$ regressions could only detect epistasis of the complementary type (Allard, 1957). All tests on the $F_{1}$ generation might also lead to erroneous conclusions because of the fail- 
ure of 2 or more assumptions compensating each other (balanced failures). Coughtrey and Mather (1970) and Feyt (1976) have shown that these tests would detect epistasis only if the genes were independently distributed among the parents.

None of the 4 examined failures of the hypotheses could be rejected. The distribution of genes among parents is not independent, multiple allelism must be suspected, heterozygosity of the parents is probable as the character seems to be controlled by numerous additive loci, and, finally, we cannot neglect the possible presence of duplicate epistasis. The magnitude of deviation to the assumptions could not be supposed to be small because of the possible occurrence of balanced failures (eg, dispersion caused an overestimation of degree of dominance whereas partial heterozygosity was likely to underestimate it, Hill, 1964).

Quantitative genetic data on partial downy mildew resistance was of practical interest to breeders. Initially, they were valuable for identification of those single crosses with high resistance and parents with high combining ability for resistance. We observed that 'MR-1' had the higher GCA value but the variety 'PI 124112', with a slightly lower GCA value, appeared to be more stable (lower variance). No heterosis and no immune behaviour had been observed in the $F_{1}$ sample. Such diallel study is also interesting for population improvement. The high heritability of the test and a low background noise from nonadditivity indicated that downy mildew resistance can be effectively handled through recurrent selection methods.

\section{ACKNOWLEDGMENT}

We thank M Ricard and C Ferrière for technical assistance.

\section{REFERENCES}

Allard RW (1957) Estimation of prepotency from lima bean diallel cross data. Agro J 48, 537-543

Baker RJ (1978) Issues in diallel analysis. Crop Sci 18, 533-536

Balkema-Boomstra AG, Mastebroek HD (1993) Diallel analysis of partial resistance to powdery mildew caused by Erysiphe graminis $\mathrm{f}$ sp hordei in spring barley (Hordeum vulgare L). Euphytica 65, 15-21

Blancard D, Pitrat M, Jourdain F (1989) Étude de la sporulation de $P$ cubensis sur cotylédons : applica- tion à la recherche de variétés de melon résistantes. Phytopathol Medit 3, 169-175

Ceballos H, Deutsch JA (1992) Inheritance of resistance to tar spot complex in maize. Phytopathology 82, 505-512

Cohen Y, Cohen S, Eyal H (1985) Inheritance of resistance to downy mildew in Cucumis melo PI 124111. Cucurbit Genet Coop 8, 36-38

Coughtrey A, Mather K (1970) Interaction and gene association and dispersion in diallel crosses where gene frequencies are unequal. Heredity $25,79-88$

Crill $P$ (1977) An assessment of stabilizing selection in crop variety development. Ann Rev Phytopathol 15, 185-202

Danon T, Eyal Z (1990) Inheritance of resistance to two Septoria tritici isolates in spring and winter bread wheat cultivars. Euphytica 47, 203-214

Dickinson AG, Jinks JL (1956) A general analysis of diallel crosses. Genetics 41, 65-77

Épinat C (1989) Hérédité de la résistance de 3 lignées de melon (Cucumis melo) au mildiou (Pseudoperonospora cubensis). Mémoire de DEA 'Génétique et Amélioration des plantes' INAPG $50 p$

Épinat C (1992) Analyse génétique d'un plan de croisement diallèle pour les caractères de résistance du melon (Cucumis melo) au mildiou (Pseudoperonospora cubensis) et aux oïdiums (Sphaerotheca fuliginea et Erysiphe cichoracearum). Thèse de doctorat INA-PG. $169 \mathrm{p}$

Épinat C, Pitrat M, Bertrand F (1993) Genetic analysis of five melon lines to powdery mildews. Euphytica $65,135-144$

Feyt $\mathrm{H}$ (1976) Étude critique de l'analyse des croisements diallèles au moyen de la simulation. Ann Amél Plantes 26, 173-193

Gilbert NE (1958) Diallel cross in plant breeding. Heredity 12, 477-492

Griffing B (1956) Concept of general and specific ability in relation to diallel crossing systems. Aus $J$ Biol Sci $9,463-493$

Hayman $\mathrm{Bl}$ (1954) The theory and analysis of diallel crosses. Genetics 39, 789-809

Hayman BI (1958) The theory and analysis of diallel crosses II. Genetics 43, 63-85

Hill $\mathrm{J}$ (1964) Effects of correlated gene distributions in the analysis of diallel crosses. Heredity 19, 27-46

Jinks JL (1956) The F2 and backcross generations from a set of diallel crosses. Heredity 10, 1-30

Kenigsbuch D, Cohen $Y$ (1992) Inheritance of resistance to downy mildew in Cucumis melo PI 124112 and commonality of resistance genes with $\mathrm{PI}$ 124111 F. Plant Dis 76, 615-617

Kempthorne $O$ (1956). The theory of the diallel crosses. Genetics 41, 451-459

Mather K, Jinks JL (1971) Biometrical Genetics. Chapman and Hall, 2nd Edition, London 
Pitrat M, Blancard D, Epinat C (1989) A study on the variability of downy mildew and looking for sources of resistance in Cucumis melo. In: Proceedings of Cucurbitaceae 89: Evaluation and Enhancement of cucurbit germplasm, Nov 29-Dec 2, Charleston SC, 137-139

Reuveni M, Eyal H, Cohen Y (1980) Development of resistance to metalaxyl in Pseudoperonospora cubensis. Plant Dis 64, 1108-1109

SAS Institute Inc (1988) SAS/STAT User's Guide, Release 6.03 Edition. SAS Institute Inc, CARY, NC, USA, $1028 \mathrm{pp}$
Thomas CE (1982) Resistance to downy mildew in Cucumis melo plant introductions and American cultivars. Plant Dis 66, 500-502

Thomas CE, Inaba T, Cohen Y (1987) Physiological specialization in Pseudoperonospora cubensis. Phytopathol 77, 1621-24

Thomas CE, Cohen Y, McCreight JD, Jourdain EL, Cohen $S$ (1988) Inheritance of resistance to downy mildew in Cucumis melo. Plant Dis 72, 33-35

Wright AJ (1985) Diallel designs, analyses and reference populations. Heredity 54, 307-311 